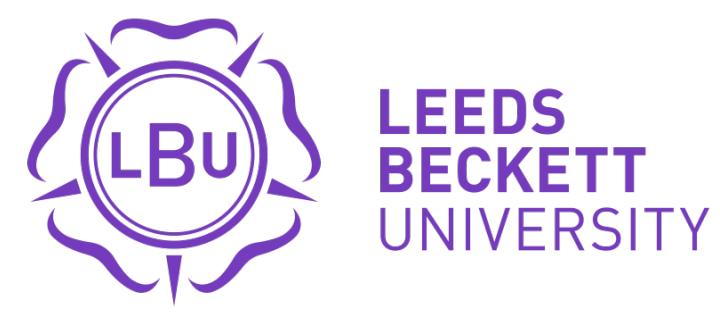

Citation:

Laredo, EA and Hill, DJ (2019) First and last and always: Streetwork as a methodology for radical community social work practice. Critical and Radical Social Work, 7 (1). pp. 25-39. ISSN 2049-8675 DOI: https://doi.org/10.1332/204986019X15491042559682

Link to Leeds Beckett Repository record:

https://eprints.leedsbeckett.ac.uk/id/eprint/5406/

Document Version:

Article (Accepted Version)

This is a post-peer-review, pre-copy edited version of an article published in Critical and Radical Social Work. The definitive publisher-authenticated version Hill, D. and and Laredo, E. (2019) First and last and always: streetwork as a methodology for radical community social work practice, Critical and Radical Social Work, 7(1), 25-39, is available online at: https://www.ingentaconnect.com/content/tpp/crsw/2019/00000007/00000001/art00003

The aim of the Leeds Beckett Repository is to provide open access to our research, as required by funder policies and permitted by publishers and copyright law.

The Leeds Beckett repository holds a wide range of publications, each of which has been checked for copyright and the relevant embargo period has been applied by the Research Services team.

We operate on a standard take-down policy. If you are the author or publisher of an output and you would like it removed from the repository, please contact us and we will investigate on a case-by-case basis.

Each thesis in the repository has been cleared where necessary by the author for third party copyright. If you would like a thesis to be removed from the repository or believe there is an issue with copyright, please contact us on openaccess@leedsbeckett.ac.uk and we will investigate on a case-by-case basis. 


\section{First and last and always: Streetwork as a methodology for radical community social}

\section{work practice.}

Dr Darren Hill. PhD.

Leeds Beckett University.

Dr Erika Laredo. PhD.

Leeds Beckett University.

\section{Abstract.}

This conceptual paper aims to introduce and explore the practice of social streetwork.

Streetwork is located as a historical professional discourse that has contemporary relevance fora rapidly changing and globalised world. Streetwork as a practice discourse occurs across a range of community based helping professions including social work, youth work and community work. The social work profession is increasingly becoming clinical and situated within statutory organisations placing a greater emphasis on outcome based targets, rather than building relationships; and as a result of austerity, traditional youth workers are becoming invisible, often moving into statutory education settings and complex needs welfare agencies. This paper will argue that for the broad helping professions to remain relevant we must engage with vulnerable and complex populations where we find them: at a street level - promoting a direct practice of social justice at a micro level. Within this discussion, we will define and explore a streetwork approach by examining the methodologies and objectives of street work practice. We will argue that by keeping to its 
origins of using informal and non-formal education as its primary tools, street work as an intervention works to combat poverty, social exclusion and discrimination. The paper articulates a foundation for practice based on the promotion of low threshold interventions with complex and hard to reach social populations. One of the key themes we will explore is how to locate streetwork practice as a form of social support, accompaniment and as a tool for promoting social inclusion and social democracy.

\section{Key Words.}

Streetwork; Social Support; Social Justice; Low Threshold Intervention; Social Pedagogy.

\section{Setting the scene: street work.}

This paper will begin by locating the concept of streetwork in its professional practice, but also as an academic discourse within a wider social political and economic context. It will then further explore the direct application, objectives and methodologies of streetwork as a form of social inclusion and accompaniment. Streetwork is neither a new concept nor a redefinition of practice; rather it is a hybrid practice, floating practice often found within multiple organisations, agencies and methodological traditions, all of which have deep roots in community work practice. In the following discussion we will explore and locate streetwork as a political, ethical and philosophical activity that seeks to promote social justice in a dialectical educational relationship, that itself is congruent with the philosophy and practices of 'care of the self' as articulated in the works of Michel Foucault (1978; $1985 ; 1986)$ and Pierre Hadot $(1995 ; 2004)$. Furthermore, it is a practice with a commitment to working collaboratively with service users, using a more horizontal model of advocacy and empowerment, and thus has the capacity to humanise social relations between the 
professional and the excluded. In the paper we advocate that limited professional 'silo' thinking across broad social, welfare and community services employing 'helping professionals', often hinders rather than helps the populations we serve. What we are thus proposing is a model, which recognises the relational nature of the work as the core to practice.

It is from within this organisational, social, economic and political context that streetwork has emerged, or some may argue re-emerged (Ferguson, 2004). Over the last 50 years within the UK, we have seen the helping professionals of the emergent welfare state, divided and separated into sub categories in their formation, education and practice. While this serves central government and philanthropic funding streams as well as professional interest groups, it ultimately acts as a point of contention for supporting the individuals and communities we serve, who require supporting and helping relationships within a social context. Indeed we would argue it is precisely this relational aspect of the practice that puts it at odds with much of the dominant orthodoxies of neo-liberalism in which politicians and policy makers, and stakeholders, demand more and more evidence that streetwork is meeting needs and that workers demonstrate this in a variety ways, including making evident that their practice represents 'value for money'. A central concern for contemporary streetwork practitioners is how to work in a meaningful way that meets the needs of people who often have complex and chaotic lives, and be able to develop this work over a longer time frame, when most funders have very specific targets and aims.

We will argue in this paper that: social work, youth work and community work, as well as support work related professional roles, have more in common than they hold in difference 
(Hill et al, 2018). Premised on this thinking we are working with a definition of streetwork as a coming together of ideas, methodology and interventions, and will thus argue here, that this approach requires recognition and articulation in order to claim it as a distinct practice.

Historically a streetwork approach was the point of origin for many of the community based 'helping' professions, and as such can be considered as the genesis of these practices (Ferguson, 2004; Garland, 1985). Social streetwork is a fluid concept and practice and it is this adaptability where we see its strength. In an age of austerity witnessing the retreat of social welfare institutions and the transfer of responsibility for welfare from the social to the individual, the time and space is now critical for a re-articulation and underlining of what makes this practice so vital (Hill et al, 2016; Seymour, 2014). From this perspective the (re)emergence of streetwork can be understood as a response to the crisis within welfare services. In a complex world where the contradictions of capitalism are laid on the shoulders of individual citizens a practice is required, which transcends traditional welfare institutions and understands the severity and the implications of these social and economic contradictions. Key to our discussion is a view of Streetwork as a radical practice, which has at its core an ethic and knowledge of its history as an informal educational practice, which will meet the needs of the populations it works with, and not from a deficit lens as a rescuing mission for 'lost souls'.

The social streetworker informed by a social justice approach, has an explicit commitment to build into outcomes, a desire for transformative systemic change, as such, the social street worker recognises themselves as an agent for change and promotes their work as a challenge to inequality and a response to injustice. Those who live street connected lives are all too frequently hidden from traditional vantage points, which render them more vulnerable, social justice is therefore embedded centrally to our methodology and practice, because of a 
commitment to amplify the agency of people on the margins of their society. Working together with the service user activates the social citizenship of these disenfranchised groups. A streetwork approach is to work with groups in terms of advocacy and empowerment to coproduce strategies and interventions that work. Equally, the approach is informed by a commitment to promote agency in addition to having an understanding of the ways in which structural barriers lead to inequality and thus must be addressed as an inherent part of the problem.

\section{What is street social work: Introducing street work.}

Streetwork can be considered variously as a context, discipline, ethical standpoint and intervention within the disciplinary fields of youth, community, social work and health services. It is an historic approach that is finding new life within the contemporary political and economic environment (Ferguson, 2004; Garland, 1985). As a relatively new intervention, yet one that has deep roots in historical traditions, here we are defining streetwork as emergent field of practice. The paper proposes that the term streetwork is both provocative and simultaneously an invitation for further discussion; moreover that this discussion is actually framed in a much wider analysis of current service provision. These considerations notwithstanding, in order to develop a professional narrative that best captures a streetwork approach, and to begin an effective dialogue, we are defining street work as a 'helping profession' related activity in a very broad, pragmatic sense. This reference to helping professionals is deliberately broad as it seeks to encompass all forms of youth, community and social support work. Adopting this position promotes ideas of streetwork as more than simply a technical activity; As a 'helping profession' activity streetwork belongs to a wider professional discourse as an approach and intervention that aims to build emancipatory practice with displaced and socially marginalised 
populations. Dynamo International, the international street work platform, defines street work as an activity which:

"Can give (back) to people in difficulties the power to act in their own lives and move towards improved wellbeing, using the values of justice, equality, human dignity and solidarity. Through their proximity or their integration into the living areas of these vulnerable people, the street worker remains the first link in the chain of support and state aid."(2008)

In using these ideas to describe the role of the streetworker, Dynamo helps us to see that we need a much broader definition of its work, it is an intervention which transcends the traditional boundaries of professional practice, furthermore the approach draws from a much broader academic interdisciplinary framework; urban geography, social science, nursing, housing and psychology, all of which have something useful to contribute to the growing discourse of street work. The street has historically been the locus of professional and institutional related development for social work orientated helping professions, all of which have played a significant role in the development of social, and other related welfare work services. Historically (and to a certain extent still today), this work was done by Christian philanthropists informed by ideas of street rescue (Payne, 2005; Williams, 1993). Those who engaged in early street outreach were people disturbed by the damage wrought by 19th century industrialisation and urbanisation in the UK and Western Europe. This dual process of industrialisation and urbanisation underpinned by liberal capitalism gave rise to unequal social and economic conditions and contradictions all of which, required formal and informal structural intervention (Hobsbawn, 2004). The street thus became the very first point of contact, offering welfare and a means of addressing these contradictions of capitalism and social and economic inequality (Ferguson, 2011; Hill et al, 2016). Beyond the 19th Century, streetwork has continued to develop as both a methodology and practice remaining a central 
point of contact for vulnerable service user groups. The mid twentieth century saw the development of a comprehensive welfare state within the UK. The development of large centrally planned post war institutions that provided education, health, criminal justice and welfare services helped shape a new form of streetwork (Hill et al, 2018). This new form of street work served those individuals that often fell between the services of the large-scale institutions. From this period, we see the emergence of targeted streetwork provision in the form of detached youth work and outreach work within mental health, criminal justice and social services (Fletcher \& Bonell, 2009; Hill et al, 2015). The idea of peripatetic youth work, sometimes described as detached work was enshrined in the Albemarle report of the 1960s, which recognised that not everyone could, for one reason, or another access the 'space and place', and that youth workers should extend the repertories of their activities to incorporate those left outside. This report acknowledges that a low threshold practice to engage young people on their terms was fundamental to offering an inclusive practice.

"We have in mind the coffee bar sited strategically at the sort of place where they tend to congregate, the 'drop in' club - the experimental youth centre or workshop-We would go even further and suggest there is also a need for experiment with peripatetic youth workers, not attached directly to any organisation or premises, who would work with existing groups or gangs of young people. Only by going out to young people shall we discover how to gain their confidence, to meet their needs and to make them aware of more genuinely rewarding pursuits." (HMSO, 1960)

The move away from centrally planned state services through the process of deinstitutionalisation during the late twentieth century gave rise to a new age of communitybased care. This transfer of vulnerable populations from the traditional institutional warehouses of the asylum, special school and hospital has placed a visible minority of highly vulnerable people in a community context (Hill et al, 2018). While initially claimed as a 
progressive move, community care has been used opportunistically by governments to fragment public services and transfer services to both charities, non-governmental organisations and the private sector through a process of competitive tendering. The move to community based service provision has increased the need for a streetwork approach to engage and work with those individuals who are hard to reach, both detached youth work, and assertive outreach services (often located within mental health, housing, and addiction services) have flourished within this context. While we recognise that contemporary streetwork can be viewed as having firm roots within the historical traditions of street rescue, detached youth work and outreach provision, we must also acknowledge that streetwork as an emergent field of practice needs to move beyond service provision that is both targeted and conditional. Indeed the idea of Streetwork that we are promoting is a practice informed by radical educational philosophers, Freire, (1968) Dewey, (1938) Oakeshott (1970), who counsel pedagogues to listen and learn from their students, rather than impose solutions from above. Of course, this kind of radical practice takes time and thus is at odds with short term outcomes focussed targeted work. There are real contemporary challengers for detached and outreach workers, particularly when the social agenda is so focused on 'prevention': "The concept of prevention is used in very different fields of activity, and therefore can be interpreted in many ways, often resulting in confusion. For example, police prevention of criminal behaviour has nothing to do with socio-educational prevention work on the streets. Too often used as a floating message, the term 'prevention' is adapted to all kind of contexts. It is unsurprising to find real confusion, and a difficulty in grasping a proper understanding of the work of streetworkers." (Dynamo International, 2008) Those engaged in streetwork will recognise the 'floating messages' and fluidity of their profession and thus the challenge is to withstand the pressures from other agencies, like the 
police, who equally make a claim to working with street based populations, when the fundamental philosophical and ethical underpinning of such practice is absent.

After decades of neo-liberal globalisation and increasing austerity; welfare is more conditional than ever, and the consequences for the most vulnerable populations is more acute, particularly those who cannot navigate the increasingly conditional social relationships. All too frequently vulnerable individuals with multiple and complex needs have difficulties conforming, performing and adapting, and therefore frequently find themselves at street level with little support, and this is where the streetworker comes into their own. The difference between street based services and more traditional centre based ones, is that evidently that the interventions happen on a street level. A street worker describes the difference like this:

"I don't mind if they don't come to their appointment, or anything, as long as they know I am there. I'll come back every day regardless of someone saying F off or not turning up. There are no rules about how we support our clients. We are just there."

(Outreach Worker, Simon on the Streets).

Street work then is a relational practice dependant on building good relationships with service users, where trust develops through an understanding of 'where the other person is at', in this sense it is a slow burn rather than a 'quick fix', a process of simply being there and 'walking with'. Streetwork thus reveals some of the contradictions right at the heart of current social welfare provision, the kind of contradiction that troubled Lipsky (1970) in terms of being able to successfully mediate between necessary outcomes whilst still delivering packages of support.

"To deliver street-level policy through bureaucracy is to embrace contradiction. On the one hand, service is delivered by people to people, invoking a model of human interaction, caring and responsibility. On the other hand, service is delivered through a bureaucracy, invoking a 
model of detachment and equal treatment under conditions of resource limitations and constraints, making care and responsibility conditional." (Lipsky, 2010:71).

This point is further underlined by Dynamo International (2008) in their description of the street worker as 'the first and last point of contact' for those unable for whatever reason to engage in 'traditional, office based settings. Streetwork at its very heart is a process that places emphasis on meeting people on their own terms, journeying with them both physically in a geographical sense, and perhaps even more importantly, socially and psychologically. A street work approach offers greater flexibility in its approach to working with the vulnerable and needy, for example, one of the street workers interviewed described this process:

"Well what we aim to do is emotional and practical support. Our focus is completely on emotions and empathy... So I don't mind if our client's aren't able to make the changes that we as a society would want them to make. So if they stay the same, at least they have had a person to support them and listen to them and be there with them"

(Outreach Worker, Simon on the Streets).

Streetwork can be articulated as the practice of working alongside the person, seeing them first and foremost as a human and not a service or organisational outcome. It offers recognition that people are more than a process or result within a pressurised and demanding service provision context. It is through this understanding of working beyond traditional disciplinary and structural boundaries that the ethical underpinning becomes clear.

\section{Street work: a professional discipline and activity.}

Streetwork has evolved from contemporary service provision in the disciplinary fields of youth, community, social and health care practice, in part, as a response to the significant 
economic and social change within late modern society. Service provision traditionally is provided in a health clinic, a social service office, and community centre, or within a fixed geographical area. The service user travels to the service, or the professional will visit the service user at a place of their choice. Streetwork has developed as a response to the needs of those individuals who often fall between the gaps of more traditional service provision, those experiencing extreme mental distress, and undiagnosed trauma. Those who find it difficult to regulate themselves or be regulated, often living at the margins of society and only visible at a street level; the homeless, refugees, sex workers, substance users, young people and people experiencing mental distress. In the context of diminishing resources and a foregrounding of outcomes and impact as measures of how and where to direct those resources; work with socially and economically marginalised groups is easy to cut which means vulnerable individuals with multiple and complex needs fall through welfare safety nets. Streetwork as an approach and methodology requires an open-ended and fluid intervention free from the usual strictures of recording clear outcomes. This position is best summarised by a street worker who describes her everyday work:

"A lot of my approach is just going 'hi' and I'll carry on walking. I won't ask someone how they are necessarily. If they don't seem up to that conversation and with other clients, if one looks up and says 'hi', I will go sit down with them. Then you go from there. It's not up to me. I can't push a relationship on someone. People move at their own pace to build a relationship, it's quite daunting building relationships."

(Outreach Worker, Simon on the Streets)

As an eclectic discipline informed by a multi-dimensional approach, streetwork nevertheless is not devoid of rigour or structure in its methodology. This diverse and eclectic approach are positive; eclecticism is premised on a critical acceptance of diversity in practice and 
acknowledgment that no one theory can answer the complexity of meeting the needs of social street work service users-subjects (Yu-Te \& Lin, 2016). The approach we are drawing on has some resonance and commonalities with the work of Lehman \& Cody (2001) and informed by the following concepts:

- A focus upon relationship based interactions that place the subject-service user as the centre of change.

- A commitment to flexibility in the utilisation of problem solving approaches in providing direct and indirect advocacy and support with the subject-service user.

- $\quad$ Assessment and communication methodologies that focus on addressing issues such as diversity, oppression and discrimination.

- $\quad$ The deployment and selection of evidence based methodologies from broad professional disciplines that service the subject-service user best.

As a professional discipline, streetwork must be open access and based on developing a working relationship. Above all a successful streetwork approach is about the proximity to street based populations, and thus having a good, understanding of the precarity of a life predominantly lived on the streets. A good example of this is knowing for example, that a sex worker who has been up all night will never, despite the best will in the world, make an appointment set for the morning. Streetworkers thus become the first and last port of call for people experiencing some form of social, mental or health related crises at a street level, usually because all statutory options have failed. Streetwork starts from the premise that you begin the work where you find the service user and in response to their needs. One street worker reports that: 
“One of my clients, it's taking me a year to engage. We have a really good working

relationship now; because I have never pushed him. It was up to him. He knew I was going to walk past him every day. He knew I'd ask him if he wanted a fag. But that was it. I think a lot of the time people can be overbearing asking what going on what's wrong with you." (Outreach Worker, Simon on the Streets)

Fundamental to this approach is the idea of working where people are and where they feel comfortable engaging. Street work is the wilful act of accompaniment; of positioning yourself alongside someone who is beginning to undertake a complex social journey. The idea of offering support is the belief that it is this dialogical approach that at its core will develop self-esteem, work on personal and social skills, and enable participation and inclusion in social life on terms defined by the service users.

Social street work can also be explored as a professional activity that has congruence with the ideas of Foucault (2006) in his exploration of the techniques of self and the art of self-care. The classical ideas of the Greek, Roman, and Hellenic position of epimeleia heautou (care of the self) are integral to the social street work relationship. Foucault highlights that epimeleia heautou or care of the self can be located as follows:

"(1) It is a general attitude, a way to consider things, to be in the world, to perform actions, to relate with other subjects. The epimeleia heautou is an attitude: regarding the self, regarding others, regarding the world.

(2) It is a way to pay attention, to look. To preoccupy for the self, to take our gaze outside. It is about paying attention to what we think and what happens to the thought. In this fashion, it is bound with the word melete that means both exercise, and care and preoccupation. 
(3) The epimeleia heautou does not appoint the attention or global or general interest over oneself. But instead, it deals particularly with the techniques or actions through which the subject takes care of itself, of how it purifies, modifies, and transfigures itself, in other words, how the subject is being formed.” (Foucault, 2006: 28)

Reflecting on the previous quote, social street work can be considered a practice and technique of care of the self through the process of relating to, and supporting others within a helping relationship - at a street level. This process of care is a deliberate act of accompaniment with the individual that seeks to support those who often do not have access, or are excluded from, broader welfare-care services, hence, the need to support acts of selfcare and self-direction in the helping relationship.

\section{Objectives and methodologies of street work.}

\section{Going beyond traditional service boundaries: low threshold interventions.}

Contemporary social street work practice works at the margins of traditional statutory service provision and works with socially marginalised and excluded communities. A key feature of street work involves working with complex trauma and neglect; one street worker describes her typical service user as having:

"Suffered trauma as a child, on average it's sexual abuse. They've either been in care or stayed in really abusive households... The people who were there, who were meant to protect our clients didn't." (Outreach Worker, Simon on the Streets)

Street workers work with those who do not fit within an outcome focused service delivery provision. Often individual or groups who respond best to a street worker approach are those who cannot adapt to the rigidity of statutory welfare requirements, outcomes or conditions. 
Outcomes are central to modern social welfare, education and health services and promoting social change in a top down mechanistic format is paramount in these contexts (Hill, 2016). The streetworker by contrast works with individuals who fall through the gaps of service provision; the refugee who has no access to public funds or support; the mental health service user who has a drug dependency; the homeless person with complex mental health problems, the sex worker who has been traumatised through unpunished rape the list is endless. The main point is that streetwork identifies with those who are hard to engage and hard to reach, and because of the complexity of their needs are forgotten. One street worker summarised their ethical and methodological outlook in a pithily as: “We don't condemn or condone". The core methodology to deliver this objective is a commitment to low threshold practices. Low threshold or harm minimisation approaches are models developed when working with socially isolated and excluded communities (Goldberg et al, 2001; Hill et al, 2015). Harm reduction does not condone, but promotes the means to keep safe in otherwise dangerous activities; needle exchanges for drug users and condoms and rape alarms for sex workers.

Although thus far we have promoted streetwork as an outreach service, actively going to meet people in their own domains, we nevertheless also recognise that a streetwork approach may also be applied in a more traditional outcome focused service. In this latter case the context may shift and the low threshold intervention rests with the worker utilising the method as a means of facilitating communication and as an engagement strategy to improve and promote better outcomes for the service user and their organisation; sometimes simply by being flexible with how a service is delivered, adapting times and even spaces to fit demand. Regardless of the organisation and the practice, despite the different points of contact and outcomes, we are working towards developing relationships in order to promote better social and material outcomes for those we work with. 


\section{Social support and accompaniment.}

Streetwork practice as a methodology is underpinned by a non-judgmental approach, not simply in terms of professional evaluation, but also in terms of professional engagement. Simply put, this means a worker cannot enter a relationship with a pre-determined outcome, which is difficult as many traditional services are delivered on the premise of enforced change in behaviour, or social context. Streetwork aims to work alongside the individual or in their communities; listening to the service user and providing informal social support to promote social change. Using a dialogical approach solutions are co-created rather than imposed. The practice works with people using a holistic model and is informed by a rich history of social pedagogy and informal education and social justice (Storo, 2013). Working alongside service users the approach promotes social learning with the aim of empowering educating and enabling the service user to operate better within the social welfare, health, education frameworks. As a methodology streetwork promotes social inclusion, but only at the pace of the service user and then only on their terms. Building on the premise of low threshold support, a central aim of streetwork is to develop a helping relationship based on mutual social learning and education. Central to this approach are the following principles.

- A grounded education of the head that promotes cognitive learning and problem solving.

- An awareness of a person's emotional and spiritual development, locating their heart and allowing them space and time to develop as a whole person. 
- $\quad$ Direct support and guidance to build practical skills of the hand, from independent living and self-care techniques, to managing daily activities (Cameron \& Boddy, 2005).

While these concepts and approaches are neither new nor revolutionary, they require a reflective and pragmatic approach centred on the individual. This whole systems approach of accompaniment rather than direction lies at the heart of social street work practice. This is where the truly radical community work perspective is located. In a professional context of fast-paced assessments, interventions and outcomes within the helping professions, streetwork repositions the helping relationship, slowing down our activity as we travel with and work alongside the service users. This slowing down of practice and repositioning ourselves within a streetwork context allows for a radical community work perspective to be explored.

\section{Inclusion and social democracy.}

As we have explored previously the street worker starts from where the service user is at; that may be a physical location such as the street; but, it is also a mental and potentially emotional place. Developing engagement is a horizontal not hierarchical process, a bottom up approach, which involves listening to the experience of street-based individuals and communities and allowing them to formulate their own responses to their own social and material conditions (Goodman et al, 2014). This may seem a natural response to working in a humanistic manner with others and often does form part of the professional and ethical make up of all professions as an aspirational ethical and value based system, yet there are frequent problems with many of the statutory professions delivering from traditional welfare institutions, and often their practitioners become compromised delivering social policy at a street level (Lipsky, 2010). A streetwork approach supports practitioners to address the inherent 
contradictions within traditional social support and direct practice and street workers have a commitment to eliminating the inherent power relationship within social and welfare service provision. Participation, and the co-creation of services that are fit for purpose is a longerterm goal of the practice.

Clients all too often face social complexity with little or no personal agency over their circumstances. In most interactions with public institutions, they are locked into a voluntary or coercive relationship. Even in a voluntary situation, the lines become problematic (Lipsky, 2010). Building on its low threshold approach and ideas of social accompaniment, streetwork seeks to address the power relationships between service user and institutions, acknowledge them and promote practices that address this structural imbalance. This participatory approach and standpoint is key to addressing inequality and has been used within health and community services with some success (Marston et al, 2016). Integral to the social streetwork approach is the development of self-advocacy and citizen advocacy (MacLean \& Harrison, 2009). While streetwork can deploy a social casework approach in its direct form of social support, it is important to acknowledge that social support offers a limited one-dimensional approach to problem solving. In managing social complexity and exclusion, we recognise that individuals can and should act as self-advocates and work with larger social movements and collectives (Vosburgh \& Hyman, 1973). A streetwork approach is underpinned with an understanding of the growing structural inequalities inherent in contemporary neo-liberal globalisation. Another important dimension of the streetwork approach is to challenge the pathology of individualisation and somatisation of complex social problems (Mills, 1943). Whilst working pragmatically with individual cases streetwork promotes collectivity at the centre of its approach by de-centring the dominant discourses of self-care, individualism and the culture of the self, and re-asserting the primacy of self-advocacy. 
Self-advocacy is a primary method and outcome for street social work it is a powerful intervention and experience. When identifying structural issues that impact upon street based populations it is important that we form groups, make links and begin to express the commonalities that locate us at a street level. Self-advocacy groups are the start of a journey, which require support and coordination in terms of developing a group work approach in their initial stages. Confidence skills, assertiveness training and educational support and resources are the types of competencies facilitated by the street worker. Self-advocacy has a powerful history and past record of achievement in supporting marginalised service users to make their voices heard and their issues visible within a political and institutional area (Maclean \& Harrison, 2009; Freidman et al, 2014). A longer-term aim of a streetwork approach is to identify successful strategies of inclusion and to promote social democracy as a key to the process of citizen advocacy. The streetworker becomes the interlocutor for those unable to do so for themselves and as such promotes an awareness of these issues to external institutions. The promotion of citizen advocacy by street workers, rather than by street based populations themselves, should only be done in circumstances where the street based population is too vulnerable, chaotic, marginalised or lacking in self-confidence, poor communication skills or language capacity.

\section{The contemporary challenges facing streetwork as a methodology for radical community social work practice.}

There are several very challenges facing streetwork that need to be addressed if we are serious about developing streetwork as an approach for contemporary radical community and social work practice. The social, economic, political and cultural contexts which frame our work not only present us with complex challenges, but requires a commitment to, and understanding of an ethical practice, which emphasizes certain values and concerns: the 
worth placed on the person, the importance of critical thinking, and the need to examine the 'taken for granted'. Streetworkers do not operate from neutral positions, but understand the prevailing political and economic contexts that frame our work, and pick a side.

Our lived experience is marshalled by individualism, underpinned by competition, systematic economic inequality and social exclusion. Streetworkers walk with and accompany the marginalised and socially excluded wherever they may be; the city centre substance user; the street based sex worker; the sofa surfing care leaver; the migrant lost in the city; and the older adult isolated and alone walking the city during the day. Streetworkers do not operate from neutral positions but understand the prevailing political and economic contexts that frame our work, and pick a side.

An insidious feature of contemporary neoliberal political and economic discourse is its ability to hijack and subvert emancipatory practices and social movements, and re-package them within a framework that supports the dominant political and economic system. Radical social change is reformed and becomes an opportunity to reinforce the dominant political and economic model of neo-liberalism. The process of deinstitutionalisation and community care has paved the way for a transfer public assets and services into the private for-profit business. Service user autonomy and rights based social movements have become a mechanism for introducing market based 'personalisation' reforms that transfer responsibility for care from the state to the individual. Markets now determine all of our actions and dictate our working patterns. In the context of austerity driven cost-cutting, multi-agency approaches, framed in narratives of early intervention and/or prevention strategies, there is a need for streetworkers to be clear about who their primary client is, and what makes this relationship different to other practices. In practice, this means being transparent, developing a low threshold 
approach being accepting and working with individuals and groups in ways that are beneficial to them, using flexible time frames that work for the respective group. There is always the potential for streetwork to be used as a formula for reducing and removing much needed traditional service provision given austerity measures and the reduction in public services, typically in the areas where streetwork finds itself; youth, mental health, homelessness, street sex work, essentially the vulnerable and hard to reach areas Streetwork is not a substitute for good universal health, education, welfare, criminal justice or social service provision. Streetwork provides a different, if complementary service, functioning as =a catalyst and key point of contact for those that fall between traditional service provisions. Streetwork is not, and nor should it ever become a replacement for services or service provisions; it is not a methodology for devolving the cost of service provision from the state or agency to the individual. Streetwork is a complementary practice to formal welfare, and is most successful when it sits alongside other service providers; education, criminal justice, and health and social services, The challenge for street workers then is to acknowledge that street work is itself a 'floating concept', and easily manipulated when a strong account of what street work is, and the ethical principles that underpin it, are absent. In this scenario there is the potential to become a form of social control or soft policing. By placing ourselves alongside vulnerable populations, we present a unique opportunity for surveillance and observation of marginalised social groups. There is a valid argument that all social work provision has a tendency towards social control, and that may be true within its statutory contexts; social work often works in a conflictual helping relationship often within child protection decision-making processes, or providing economic rationalisation and resource management within adult social care. 
With these challenges in mind, it is important that we develop, enhance and promote streetwork education and practice accordingly. In countering the manipulation of streetwork, we must start from where the practitioner is at. Firstly, streetwork as a methodology for radical community based social work activity can be practiced from within traditional statutory social work institutions as well as more informal community based voluntary organisations. To practice streetwork is to move beyond the limited silo based thinking or organisations and outcomes; we are more than the roles defined by social policy and safeguarding agendas. As a methodology and practice streetwork, is a process for social work and community-based practitioners to reimagine their space of encounter with service users and to meet them on their own terms to develop a more equitable and supportive helping relationship To develop the streetwork approach requires both a shift in thinking, but equally a shift in professional organisation. Those social workers and community-based practitioners need to find organisations that allow them to meet up and discuss streetwork as a practice, there are many platforms both locally, regionally and internationally. The Social Work Action Network, the Federation of Detached Youth Workers and Dynamo International, are all useful networks, which offer space to reflect on practice, and meet other like-minded practitioners seeking to challenge the dominant modes of practice. Through cooperation, reflection discussion, seeking out allies and building networks we can begin to re-imagine community based social work practice. We need to work with our professional associations and allied Trade Unions to make effective challenges to the dominant models of economic and political governance and in turn, these organisations can begin to lobby for systemic change. The streetworker understands that advocacy, or being a mouthpiece is an intrinsic part of their role. Streetworkers publicly address and claim the needs, problems, and interests of the people they work with. This may be through the vehicle of political or local activism, but working collaboratively with the service users to affect social and political change. 
Poverty and inequality are not choices made by individuals, they are a direct expression of political and economic policy, we have a choice about how we would like society to look and parliamentary democracy offers us a vehicle for creating a better or 'good' society. The key message for challenging the dominant models of political and economic governance is the ability to connect our practice with service users, professional platforms, trade unions and political parties. We live within a system that seeks to isolate and individualise our thinking and practice, to be truly radical we need to connect, starting at a street level and create communities of resistance to the dominant political, social and economic narrative.

\section{Tentative Conclusions.}

This paper has suggested that we think about streetwork as a useful approach to working with marginalised and excluded communities. We have argued that a streetwork approach is essential for developing a more humanistic relational approach for working with people. Streetwork is informed by ideals of social justice, inclusion and principles of empowerment and offers an approach to address structural inequalities by understanding the nature of power. Streetwork actively seeks to co-create solutions by valuing the lived experiences of some of the most marginal populations. In promoting and enhancing social justice, street work is good social work practice that draws on empowering values and skills. Hence, streetwork lies at the heart of good practice and offers something to all of us. 


\section{References.}

Atlee, C.R. (1920) [2016] The Social Worker. London: G.Bell \& Sons. [Internet] available from < https://archive.org/stream/socialworker00attliala\#page/22/mode/2up > [Last Accessed August 2016].

Burawoy, M., Blum, J.A., George S., Gille, Z., Gowan, T., Haney, L., Klawiter, M., Lopez, S.H., Rian, S.O Thayer, M. (2000) Global Ethnography. Berkeley: University of California Press.

Burawoy, M (2009). The Extended Case Method. Berkeley: University of California Press.

Cameron, C. and Boddy, J. (2005) With Heart, Head and Hands. Community Care, 19th 25th May 2005, pp 36-37.

Courtney, J, \& Hickey, R. (2016) 'Street-Level Advocates: Developmental Service Workers Confront Austerity in Ontario', Labour / Le Travail, 77, pp. 73-92.

Dewey, J. $(1938,1998)$ Experience and Education, Indianapolis: Kappa Delta Pi.

Dynamo International. (2008) International Guide on the Methodology of Street Work.

[Internet] Available from < http://www.travailderue.org/wp-

content/uploads/2012/08/international_guide.pdf> [Last Accessed September 2016]

Dynamo International. (2010) Social Street Work. Brussels: Dynamo International. 
Ferguson, H. (2004) Protecting Children in Time: Child Abuse, Child Protection and the Promotion of Welfare. Basingstoke: Palgrave-Macmillan.

Ferguson, H. (2011) Child Protection Practice. Basingstoke: Palgrave.

Fletcher, A \& Bonell, C. (2009) Detaching youth work to reduce drug and alcohol related harm. Public Policy Research, 15, 4, pp. 217-223,

Friedman, M. (2002) Capitalism and Freedom. London: University of Chicago Press.

Friedman, C, Arnold, C, Owen, A, \& Sandman, L. (2014) "Remember Our Voices are Our Tools:' Sexual Self-advocacy as Defined by People with Intellectual and Developmental Disabilities', Sexuality \& Disability, 32, 4, pp. 515-532.

Freire, P, (1970) Pedagogy of the oppressed. New York: Continuum.

Foucault, M. (1978) The History of Sexuality: An Introduction (Volume I). New York: Random House.

Foucault, M (1980). Power/ Knowledge. London: Harvester.

Foucault, M. (1981). The Will to Knowledge. London: Penguin.

Foucault, M. (1985), The Use of Pleasure: The History of Sexuality (Volume II). New York: Random House. 
Foucault, M. (1986), The Care of the Self: The History of Sexuality (Volume III). New York: Random House.

Foucault, M. (2006) The hermeneutics of the subject: Lectures at the College de France, 1981-1982. New York: Picador.

Garland, D. (1985) Punishment and Welfare: A History of Penal Strategies. Aldershot:

Gower.

Goldberg, D, Burns, S, Taylor, A, Cameron, S, Hargreaves, D, \& Hutchinson, S. (2001) 'Trends in HCV Prevalence among Injecting Drug Users in Glasgow and Edinburgh during the Era of Needle/Syringe Exchange', Scandinavian Journal of Infectious Diseases, 33, 6: $457-461$.

Goodman R, A. Bunnell R, Posner S, F. (2014). What is "community health"? Examining the meaning of an evolving field in public health. Prev Med. 2014 Oct; 67.

Hadot, P. (1995) Philosophy as a Way of Life: Spiritual Exercises from Socrates to Foucault. Davidson, A.I. (Editor) \& Chase, M (Trans). Oxford. Blackwell.

Hadot, P. (2004) What is Ancient Philosophy? Cambridge: Belknap/Harvard.

Harvey, D. (2005) A Brief History of Neo Liberalism. Oxford: Oxford University Press. 
Harvey, D. (2010) The Enigma of Capital and the Crises of Capitalism. London: Profile.

HMSO (1960) The Youth Service in England and Wales (The Albermarle Report), HMSO, Cmnd. 929, London, 1960, paras. 186/7.

Hill, D. Penson, W.J. \& Charura, D. (2015). Working with Dual Diagnosis: A Psycho Social Perspective. London: Palgrave Macmillan.

Hill, D. Agu, L. \& Mercer, D. (2018) Exploring and Locating Social Work A Foundation for Practice. London: Macmillan International - Red Globe Press.

Hill, D. (2016) From policy to practice: how do community workers interpret and work with the contemporary UK Drug Strategy? [PhD thesis] Leeds: Leeds Beckett University.

Jordan, B. \& Drakeford, M. (2012) Social Work And Social Policy Under Austerity. Basingstoke: Palgrave Macmillan.

Klein, N. (1999) No Logo. London: Picador.

Lehman, P \& Cody, N. (2001) Theoretical Perspectives for Direct Social work Practice: A Generalist Eclectic Approach. New York: Springer. 
Lipsky, M. (2010) Street level Bureaucracy: Dilemmas of the individual in public Services. New York: Russel Sage Foundation.

Marston, C, Hinton, R, Kean, S, Baral, S, Ahuja, A, Costello, A, \& Portela, A. (2016)

'Community participation for transformative action on women's, children's and adolescents' health', Bulletin Of The World Health Organization, 94, 5, pp. 376-382.

Mason, P. (2015) Post Capitalism: A Guide to Our Future. London: penguin.

Mills, C.W. (1943) 'The Professional ideology of social pathologists', The American Journal of Sociology, 49 (2), 165-80.

Oakeshott, M. (1972) Education: The Engagement and its Frustration, in Dearden, R.F.., Hirst, P.H., and Peters, R.S. (eds.) Education and the Development of Reason, London: Routledge \& Keegan Paul.

Petersen, T \& McBride, A. (Eds) (2006) Working with Substance Misusers: A guide to Theory \& Practice. London: Routledge.

Rowlingson, K. (2011) Does income inequality cause health and social problems? [Internet] Joseph Rowntree Foundation. Available from < https://www.jrf.org.uk/report/does-incomeinequality-cause-health-and-social-problems > [Last Accessed October 2016]

Seymour, R. (2014) Against Austerity: How We Can Fix The Crisis They Made. London: Pluto Press. 
Standing, G. (2014) The Precariat: The New Dangerous Class. London: Bloomsbury.

Stimson, G.V. (2000) 'Blair declares war: the unhealthy state of British drugs policy'. International Journal of Drug Policy, 11: 259-64.

Storo, J. (2013) Practical Social Pedagogy. [Electronic Resource]. Theories, Values and Tools For Working With Children And Young People. Bristol : The Policy Press, 2013. Leeds Beckett University Library Catalogue.

Vosburgh, W, \& Hyman, D. (1973) 'Advocacy and Bureaucracy: The Life and Times of a Decentralized Citizen's Advocacy Program', Administrative Science Quarterly, 18, 4, pp. 433-448.

Williams, C. (1993)Who are "street children?" a hierarchy of street use and appropriate responses.Child Abuse \& Neglect. 1993 vol: 17 (6) pp: 831-841

Yu-Te, H. \& Lin, F. (2016) 'Understanding Depression from Different Paradigms: Toward an Eclectic Social Work Approach', British Journal of Social Work, 46, 3, pp. 756-772. 